\title{
Characterization of Fly Ash from Polish Coal-Fired CHP Plants for $\mathrm{NO}_{2}$ Capture
}

\author{
Aleksandra Ściubidło1*, Izabela Majchrzak-Kucęba ${ }^{1}$, Wojciech Nowak² \\ ${ }^{1}$ Institute of Advanced Energy Technologies, Częstochowa University of Technology, Częstochowa, Poland \\ ${ }^{2}$ Faculty of Energy and Fuels, AGH University of Science and Technology, Kraków, Poland
}

Received: 5 May 2018

Accepted: 8 September 2018

\begin{abstract}
To meet the growing energy demand and thereby increase power-generating capacity, the dependency on coal for power generation, are required a more environmentally friendly methods of fly ash utilization. Therefore, the priority is to characterize domestic fly ash in detail in order to ascertain its potential uses as raw material in the production of high-value products. The high silica content of fly ash makes it a potential useful source for the synthesis of nanoporous materials, such as zeolites and mesoporous molecular sieves. The physicochemical properties of fly ash coming from seven coal-fired power plants and three heat and power plants in Poland are presented in this work. The fly ash was sampled from power plants that use combustion of lignite and hard coal in pulverized-fuel boilers (PC) and circulating fluidized bed (CFB) boilers. The fly ash was examined for its morphology, chemical and mineral composition, grain size, structure and thermal stability by using advanced instrumental techniques (XRF, XRD, SEM, BET, TGA). According to mineralogical and chemical composition of fly ash, three fly ash samples are potentially useful as a raw material for making zeolite A, two samples for zeolite $\mathrm{X}$ and fly ash No. 8 for zeolite $\mathrm{Y}$. The samples with the highest content of $\mathrm{SiO}_{2}$ and $\mathrm{Al}_{2} \mathrm{O}_{3}$ (Nos. 2-6 and 9) can be used to synthesize mesoporous molecular sieves such as MCM-41 and SBA-15. Received zeolites and mesoporous sieves from these fly ash samples will be used for removing $\mathrm{NO}_{2}$ from exhaust gas, and these studies can be implemented in power plants with $\mathrm{CO}_{2}$ capture, in the process of exhaust gas purification to removal of $\mathrm{NO}_{2}$.
\end{abstract}

Keywords: fly ash; XRF; XRD; particle size distribution; BET specific surface area

\section{Introduction}

Fossil fuels will be perspective until 2030 to satisfy the demand of about four-fifths of the energy consumption in the world. Coal reserves are available for about 200 years, oil for $35-40$ years and natural gas

*e-mail: asciubidlo@is.pcz.czest.pl

for about 40-50. Coal, due to its high emissivity, is a risk for the environment. In addition, coal is the main fuel for the production of electrical energy, which is why it requires a more environmentally friendly method of fuel conversion. In Poland, the production of electricity is based mainly on coal. According to the GUS (Central Statistical Office), primary energy consumption in Poland in 2016 was 4448025 TJ, of which $39.84 \%$ was generated from the combustion of hard coal and $11.02 \%$ from lignite. Based on the statistical data, 
3258000 tons of fly ash were generated in Poland in 2016 , of which $86.7 \%$ were subjected to recovery and $11.3 \%$ were disposed of, including $2 \%$ of fly ash that were temporarily stored, while 26000000 tons of fly ash were accumulated as landfilled waste [1]. The most important areas of fly ash application are: concrete production [2], cement clinkers [3], foam glass [4], glass ceramics [5], glass [6], ceramics [7], soil amelioration [8], mine reclamation [9], alumina recovery [10], road basement material [11], geopolymer [12], adsorbents [13-22], zeolites [23-26], and mesoporous molecular sieve [27-28].

Synthesis zeolites and mesoporous molecular sieves from fly ash is one of the most effective, economical and simple methods of fly ash utilization. Due to the chemical composition (high content of $\mathrm{SiO}_{2}$ and $\mathrm{Al}_{2} \mathrm{O}_{3}$ ), fly ash is a suitable starting material for the synthesis of zeolites [29-30] and mesoporous materials [31]. Studies of these ashes presented above were also carried out to ascertain their applicability to zeolite and mesoporous materials synthesis. Coal fly ash and zeolite consist mainly of $\mathrm{Al}$ and $\mathrm{Si}$ [32], and the major difference between them is the crystalline structure. Coal fly ash is composed mostly of amorphous structure, whereas zeolite has a well-defined crystalline structure. Due to these similarities in the composition between coal fly ash and zeolite, coal fly ash is a potential candidate for conversion to zeolite [33]. The main element of fly ash, aluminosilicates, is converted to zeolite crystals by alkali hydrothermal reaction. Natural zeolites have restricted pore sizes and channels, whereas fly ashbased zeolites possess a variety of pore structures and are economically viable sorbent minerals for removing contaminants from water and gas. These synthesized zeolites can be used as sorbents and ion exchangers for removing ions and dangerous molecules from wastewater and radioactive waste, as well as adsorbents for gases containing atmospheric pollution [34-36].

In addition to zeolites, the synthesis of mesoporous molecular sieve from coal fly ash has also attracted attention owing to its high surface area (above $1000 \mathrm{~m}^{2} / \mathrm{g}$ ), large pore volume, and large pore size (approximately from 2 to $20 \mathrm{~nm}$ ) - exceeding the limitations of the microporous zeolites with pore sizes less than $1.3 \mathrm{~nm}$. The mesoporous materials also has large amounts of internal silanol $(\mathrm{Si}-\mathrm{OH})$ groups inside the pores that can be modified easily by functionalization with other useful organic groups for a range of industrial applications. Mesoporous silica synthesis from fly ash is anticipated to overcome the limitations of the microporous zeolite materials in the adsorptive removal of macromolecule pollutants [37]. These mesoporous materials can be used for $\mathrm{CO}_{2}$ capture [38-39], adsorption [40], and catalysis [41-43].

The authors intend to apply obtained zeolites and mesoporous materials for purification of exhaust gases of nitrogen oxides. While a large number of studies have been conducted on $\mathrm{CO}_{2}$ adsorption on zeolite from fly ash, the literature regarding $\mathrm{NO}_{2}$ adsorption on zeolite from fly ash as an adsorbent is rather scarce [44]. The literature regarding the $\mathrm{NO}_{2}$ adsorption on mesoporous material from fly ash as an adsorbent is rather scarce, while studies of $\mathrm{NO}_{2}$ adsorption on mesoporous molecular sieves from fly ash have not been published. The chemical and physical characterization of fly ash are required to predict and control mechanical and physical properties of zeolites and mesoporous materials. Our own research [45-46] has led to the conclusion that the most favourable sorbents from fly ash for $\mathrm{NO}_{2}$ capture are zeolites $\mathrm{NaA}, \mathrm{NaX}$ and mesoporous materials MCM-41 and SBA-15. Therefore, the characterization data of fly ash is necessary to make a high-quality zeolite and mesoporous material. The XRD test was performed in order to discover the crystalline mineral component of fly ash, and SEM is required to analyze the shape, surface and internal structure of fly ash particles. Using the XRF test, chemical composition of fly ash that can be used to categorize them into class $\mathrm{F}$ or class $\mathrm{C}$ could be ascertained. Therefore, in this paper we have presented a study of physical and chemical properties of fly ash and on the basis of these, fly ashes for the synthesis of zeolites and mesoporous materials were selected. Future studies will be targeted at synthesis zeolites $\mathrm{A}, \mathrm{X}$, and $\mathrm{Y}$, and mesoporous materials MCM-41 and SBA-15. Received zeolites and mesoporous molecular sieves from fly ash will be used for removing $\mathrm{NO}_{2}$ from exhaust gas, and these studies can be implemented in power plants with $\mathrm{CO}_{2}$ capture, in the process of exhaust gas purification to remove $\mathrm{NO}_{2}$.

\section{Material and Methods}

The samples of fly ashes were collected and prepared according to the standards BN-81-0623-01 (for slag, ash, and slag-ash mixtures). Four samples with a mass of about $0.5 \mathrm{~kg}$ were collected for each fly ash. These samples were collected from fly ash silos using a sampler. Samples were mixed together to obtained a sample of about $2 \mathrm{~kg}$. Then a laboratory sample was prepared by averaging. The required amounts of sample for the analysis were prepared by coning and quartering.

Ten different fly ash samples were obtained from seven coal-fired power plants and three heat and power plants in Poland. Sample Nos. 2, 3, 4, 5, 8 and 9 represent ash originating from the combustion of fuels in pulverized-fuel boilers (PC), referred to as fly ash (PC ash), while sample Nos. 1, 6, 7 and 10 are ash from the combustion of fuels in circulating fluidized bed (CFB) boilers, referred to as fluidized-bed ash (CFB ash). Ash sample Nos. 8 and 9 originated from the combustion of lignite (Table 1).

\section{Chemical Composition}

The investigation of the chemical composition included a determination of basic chemical composition 
Table 1. List of fly ash samples in the present studies.

\begin{tabular}{|c|c|c|c|c|c|}
\hline Ash & Power plant/ heat and power plant & Province & Fuel type* & Type of boiler & Ash type** \\
\hline 1. & PGNiG Termika Heat Power Station & Mazowieckie & HC & CFB & FFA \\
\hline 2. & Tauron Wytwarzanie Wytwarzanie Power Station & Śląskie & HC & PC & FA \\
\hline 3. & PGE GiEK Power Plant & Opolskie & HC & PC & FA \\
\hline 4. & Tauron Wytwarzanie PowerPlant & Śląskie & HC & PC & FA \\
\hline 5. & Tauron Wytwarzanie Power Station & Podkarpackie & HC & PC & FA \\
\hline 6. & Tauron Wytwarzanie Heat Power Station & śląskie & HC & CFB & FFA \\
\hline 7. & CEZ Heat Power Station & Śląskie & HC & CFB & FFA \\
\hline 8. & ZEPAK Power Station & Wielkopolskie & L & PC & FA \\
\hline 9. & PGE GiEK Power Station & Dolnośląskie & L & PC & FA \\
\hline 10. & Tauron Wytwarzanie Power Station & Małopolskie & HC & CFB & FFA \\
\hline
\end{tabular}

*HC-hard coal, L-lignite

**FA-fly ash from PC, FFA-fly ash from CFB

$\left(\mathrm{SiO}_{2}, \mathrm{Al}_{2} \mathrm{O}_{3}, \mathrm{Fe}_{2} \mathrm{O}_{3}, \mathrm{CaO}, \mathrm{MgO}, \mathrm{Na}_{2} \mathrm{O}, \mathrm{K}_{2} \mathrm{O}, \mathrm{SO}_{3}\right.$, $\mathrm{MnO}_{2}, \mathrm{TiO}_{2}, \mathrm{P}_{2} \mathrm{O}_{5}$ ) of ash performed by using x-ray fluorescence (XRF). A Minipal4 wavelength dispersive XRF spectrometer was used for this purpose. The XRF was calibrated over a range of glass compositions using standard reference materials. The major elements of the ash were given as $w t \%$. oxides. The contents of coal, nitrogen, hydrogen and sulfur were determined with the use of a TruSpec CHN/S analyzer.

\section{Mineralogical Composition}

An identification of crystalline phases present in the fly ash, along with defining their relative amounts in the samples, was carried out by means of an x-ray method on a D8 advance (Bruker) powder diffractometer equipped with a monochromatic device Ge (length of radiation: $\mathrm{CuK}_{\alpha 1}=1,5406 \AA$ ). Diffraction patterns were identified at room temperature, in the range of $6-60^{\circ}$ of 2-theta angle, with a $0.05^{\circ}$ step. Relative amounts of crystalline components in the ash samples were determined by means of an internal model method. Model diffraction patterns were received in the same measurement conditions as in the case of the selected samples.

\section{Texture Analysis}

Morphology investigation and sample textures were conducted using the scanning microscope type Tesla BS-301-Satellite, equipped with a spectrometer of energy dispersion (EDX), which allowed us to determine the chemical composition of the selected samples of materials. Preparations for SEM microscope were obtained by means of a deposition of surfaces of the investigated materials with a thin film of $\mathrm{Au}-\mathrm{Pd}$ in a vacuum deposition apparatus, followed by taking digital photos from the SEM microscope's detector of different fragments of those surfaces and with different magnification levels (5000, 15000 and 50000 times).

\section{Surface Area Analysis}

Nitrogen adsorption/desorption was conducted using the Micrometrics ASAP 2010 (Micrometrics Instrument Corporation, Norcross, GA, USA) apparatus. Before nitrogen adsorption, the samples $(200 \mathrm{mg})$ were subject to degasification in the temperature of $573 \mathrm{~K}$ for 3 hours. The apparatus was used to measure the low-temperature $\left(-196^{\circ} \mathrm{C}\right)$ nitrogen adsorption/desorption isotherm, on the basis of which such parameters were measured as: specific surface area, total volume of the pores, average pore diameter, distribution of pore volume in the function of their diameter and the distribution of the specific surface area in the function of the pore diameters. Several conclusions on the structure of the investigated compound were made on the basis of the qualitative analysis of the received adsorption-anddesorption isotherms.

\section{Particle Size Distribution}

A Mastersizer 2000 Particle Size Analyzer was used to measure the particle size distribution of the fly ash samples. Water was used as a carrier agent since it was found to be capable of dispersing and wetting the particles. An ultrasound sonicator bath was used to disperse the particles.

\section{Thermogravimetric Analysis}

Thermal analysis can provide important information about the thermal behaviour of the sample (phase transition, decomposition, etc.). A TGA/DSC1 thermal analyzer (produced by Mettler Toledo was used in this study. The fly ash was heated in a platinum 
crucible under atmospheric pressure and in a neutral atmosphere $\left(\mathrm{N}_{2}\right)$, with a flow ratio of a reaction gas equal to $50 \mathrm{~cm}^{3} / \mathrm{min}$, and in a range of temperatures between $20-1000^{\circ} \mathrm{C}$, with the heating rate equal to $20^{\circ} \mathrm{C} / \mathrm{min}$. In order to ensure accuracy of mass measurements, received TG curves were corrected (i.e., reduced) by a so-called blank test (i.e., TG curve of an appropriate inerrant sample, registered in particular measurement conditions). For temperature calibration, model substances with known temperatures of phase conversion were used.

\section{Results and Discussion}

\section{Chemical Composition}

The chemical composition of studied fly ash is presented in Table 2. The highest content of aluminium was found in samples $6(27.2 \%)$ and $9(26.68 \%)$, and the minimum aluminium content in the fly ash sample 8 $(5.13 \%)$. The highest silicon amounts were encountered in samples $3(51.69 \%)$ and $5(51.54 \%)$, and the lowest in sample $8(32.16 \%)$. The highest contents of calcium were located in samples 1 (7.52\%), 7 (9.59\%), 8 (33.25\%), and $10(6.61 \%)$, while the lowest calcium content was in samples 2 and 3. Maximum levels of un-burnt carbon were encountered in ash Nos. 1 (13.6\%) 2 (5.69\%) and $5(5.3 \%)$.

Samples 1, 6, 7, 8 and 10 were characterized by the highest sulfur content, and the lowest was in sample 9. The highest levels of $\mathrm{SiO} / \mathrm{Al}_{2} \mathrm{O}_{3}$ ratio were observed for sample 8 (6.27). Theis and Wirth [47], in studies of fly ash from various U.S. power plants, also noticed that the major components were $\mathrm{Al}, \mathrm{Fe}$ and $\mathrm{Si}$, with smaller concentrations of $\mathrm{Ca}, \mathrm{K}, \mathrm{Na}, \mathrm{Ti}$, and $\mathrm{S}$.

Kumar et al. [48] reported that an average 95-99\% of fly-ash consists of oxides of $\mathrm{Si}, \mathrm{Al}, \mathrm{Fe}$ and $\mathrm{Ca}$, about $0.5-3.5 \%$ consists of $\mathrm{Na}, \mathrm{P}, \mathrm{K}$ and $\mathrm{S}$, and the remainder of the ash is composed of trace elements.
It has generally been observed that CFA (coal fly ash) from lignite coals are characterised by higher $\mathrm{CaO}$, $\mathrm{MgO}$, and $\mathrm{SO}_{3}$ and lower $\mathrm{SiO}_{2}$ and $\mathrm{Al}_{2} \mathrm{O}_{3}$ [49]. The correlation between the high temperature melting acid group $\left(\mathrm{SiO}_{2}, \mathrm{Al}_{2} \mathrm{O}_{3}\right.$, and $\left.\mathrm{TiO}_{2}\right)(\mathrm{A})$ and the low melting basic group $\left(\mathrm{Fe}_{2} \mathrm{O}_{3}, \mathrm{CaO}, \mathrm{MgO}, \mathrm{K}_{2} \mathrm{O}\right.$, and $\left.\mathrm{Na}_{2} \mathrm{O}\right)$ (B) can be expressed by the basic oxides to acid oxides $\left[\mathrm{B} / \mathrm{A}=\left(\mathrm{Fe}_{2} \mathrm{O}_{3}+\mathrm{CaO}+\mathrm{MgO}+\mathrm{K}_{2} \mathrm{O}+\mathrm{Na}_{2} \mathrm{O}\right) /\left(\mathrm{SiO}_{2}+\mathrm{Al}_{2} \mathrm{O}_{3}\right.\right.$ $\left.+\mathrm{TiO}_{2}\right)$ ] [50]. The $\mathrm{B} / \mathrm{A}$ values for the lignite fly ashes were $1.10,0.2$, for PC fly ashes were (0.17-0.21) and for CFB ashes were 0.24-0.36, which suggests that the PC ashes are less prone to slagging than the other ashes.

The criterion in the standard ASTM C-6189 fly ash classification uses the sum of the three oxides $\mathrm{SiO}+\mathrm{Al}_{2} \mathrm{O}_{3}+\mathrm{Fe}_{2} \mathrm{O}_{3}$. For Class $\mathrm{C}$, this sum is between $50 \%$ and $70 \%$ and for Class $\mathrm{F}$ it is greater than $70 \%$. Thus, fly ash Nos. 1, 7, and 8, with a sum of oxides of $59.83 \%, 64.75 \%$ and $41.88 \%$, were classified as Class C fly ash. The remaining ashes, with a sum of oxides of $77.34 \%, 80.81 \%, 80.78 \%, 81.43 \%, 80.54 \%, 80.33 \%$ and $78.83 \%$, were classified as Class F fly ash. Basu et al. [51] informed that the burning of anthracite and bituminous coal typically produces Class F fly-ash, while fly-ash produced from the burning of lignite or sub-bituminous coal is of Class C. In Poland, ash is classified into silicate, aluminum and calcium, depending on the relative proportion of chemical components: $\mathrm{SiO}_{2}, \mathrm{Al}_{2} \mathrm{O}_{3}$ and $\mathrm{CaO}$. Thus fly ashes 7 and 8 were classified as Class $\mathrm{W}$ - calcium fly ash, and the remaining ashes were classified as Class $\mathrm{k}$ - silicate fly ash.

As mentioned above, fly ash is suitable starting material for the synthesis of zeolites and mesoporous materials. The parameter that determines ash usefulness as a zeolite is the $\mathrm{Si} / \mathrm{Al}$ ratio. The $\mathrm{SiO}_{2} / \mathrm{Al}_{2} \mathrm{O}_{3}$ content of ashes, being optimal for zeolites $\mathrm{A}$, is c.a. 2. The $\mathrm{SiO}_{2} / \mathrm{Al}_{2} \mathrm{O}_{3}$ content of ash, being optimal for zeolites $\mathrm{X}$ in the range of $2.2 \div 3.3$ and for zeolites $\mathrm{Y}$ in the range of $3.1 \div 6.0$ [52]. For the samples of fly ashes 2, 4 and 10 the $\mathrm{SiO}_{2} / \mathrm{Al}_{2} \mathrm{O}_{3}$ ratios were 2.01, 1.88 and 1.87 , respectively. Thus samples 2,4 and 10 can be

Table 2. Chemical composition of fly ash (wt \%.).

\begin{tabular}{|c|c|c|c|c|c|c|c|c|c|c|c|c|c|c|}
\hline Ash & $\mathrm{Al}_{2} \mathrm{O}_{3}$ & $\mathrm{CaO}$ & $\mathrm{Fe}_{2} \mathrm{O}_{3}$ & $\mathrm{MgO}$ & $\mathrm{P}_{2} \mathrm{O}_{5}$ & $\mathrm{~K}_{2} \mathrm{O}$ & $\mathrm{SiO}_{2}$ & $\mathrm{Na}_{2} \mathrm{O}$ & $\mathrm{TiO}_{2}$ & $\mathrm{MnO}$ & $\mathrm{SO}_{3}$ & $\mathrm{~N}$ & $\mathrm{H}$ & $\mathrm{C}$ \\
\hline 1. & 19.52 & 7.52 & 5.25 & 2.01 & 0.51 & 1.94 & 35.06 & 0.36 & 1.03 & 0.06 & 3.31 & 0.49 & 0.04 & 13.60 \\
\hline 2. & 23.90 & 2.97 & 5.39 & 1.49 & 0.40 & 2.52 & 48.05 & 0.42 & 1.09 & 0.07 & 0.69 & 0.31 & 0.00 & 5.69 \\
\hline 3. & 23.90 & 2.95 & 5.22 & 1.77 & 0.53 & 2.61 & 51.69 & 0.28 & 1.07 & 0.06 & 0.82 & 0.30 & 0.00 & 1.41 \\
\hline 4. & 25.55 & 3.87 & 7.28 & 1.99 & 0.38 & 2.05 & 47.95 & 0.41 & 1.14 & 0.09 & 1.23 & 0.33 & 0.01 & 0.94 \\
\hline 5. & 23.69 & 3.46 & 6.21 & 1.85 & 0.39 & 2.41 & 51.54 & 0.31 & 1.08 & 0.09 & 1.08 & 0.33 & 0.01 & 5.35 \\
\hline 6. & 27.20 & 5.55 & 7.79 & 1.89 & 0.18 & 2.12 & 45.54 & 0.42 & 1.00 & 0.07 & 2.64 & 0.33 & 0.00 & 2.38 \\
\hline 7. & 20.68 & 9.59 & 6.97 & 1.42 & 0.53 & 1.68 & 37.10 & 0.36 & 0.94 & 0.07 & 6.84 & 0.33 & 0.00 & 1.65 \\
\hline 8. & 5.13 & 33.25 & 4.59 & 3.15 & 0.28 & 0.25 & 32.16 & 0.46 & 0.71 & 0.40 & 12.54 & 0.18 & 0.00 & 0.79 \\
\hline 9. & 26.68 & 3.29 & 6.92 & 2.10 & 0.47 & 2.43 & 46.74 & 0.32 & 1.13 & 0.11 & 0.22 & 0.33 & 0.00 & 4.35 \\
\hline 10. & 22.92 & 6.61 & 13.06 & 1.70 & 0.16 & 2.21 & 42.85 & 0.43 & 0.94 & 0.09 & 2.83 & 0.34 & 0.00 & 3.08 \\
\hline
\end{tabular}


converted to zeolite A. Samples 3 and 5 with $\mathrm{SiO}_{2} / \mathrm{Al}_{2} \mathrm{O}_{3}$ ratio 2.16 and 2.18 can be converted to zeolite $\mathrm{X}$. Fly ash 8 can be converted to zeolite $\mathrm{Y}$ with $\mathrm{SiO}_{2} / \mathrm{Al}_{2} \mathrm{O}_{3}$ ratio 6.27 .

The presence of $\mathrm{CaO}$ in the CFA (the highest content in samples 1, 7, 8 and 10) can reduce mullite, giving higher conversion of fly ash. Trace elements such as $\mathrm{TiO}_{2}, \mathrm{MnO}, \mathrm{K}_{2} \mathrm{O}, \mathrm{Na}_{2} \mathrm{O}$, and $\mathrm{MgO}$ along with anionssulfate and carbonate appear to promote nucleation and crystallization of zeolite. Iron oxides (the highest content I samples 4 and 10) may decrease the quality of the product by incorporating themselves into the zeolite matrix, giving the product a brownish shade [53]. In addition, these cations may favor one type of zeolite over another, therefore it is important to choose the specific zeolite that can be converted from a specific CFA [54].

The samples with the highest content of $\mathrm{SiO}_{2}$ and $\mathrm{Al}_{2} \mathrm{O}_{3}$ (nos. 2, 3,4,5,6 and 9) can be used to synthesize mesoporous molecular sieves such as MCM-41, MCM48, SBA-15, and SBA16. The highest content of calcium were located in ash samples 1 (7.52\%), 7 (9.59\%), 8 (33.25\%), and $10(6.61 \%)$. The highest level of $\mathrm{CaO}$ in the investigated group of ashes was observed in samples $1,7,8$ and 10. This content is especially important as far as the direct synthesis of porous materials is concerned. Another essential factor, from the point of view of the synthesis of the porous materials, is unburned coal in the fly ash. The highest carbon content in ash is in samples 1, 2 and 5. Although the presence of the burned coal does not stop or interrupt the synthesis of the porous materials, in a final product it becomes an impurity and it lowers its overall quality.

\section{Mineralogical Composition of the Fly Ash}

Fly ash usually has silica in amorphous aluminosilicate glass, quartz and mullite. Of these, part of the amorphous silicate glass phase is the largest and most unstable in hydrothermal conditions, which leads to the highest dissolution rate and has the largest share in the synthesis of zeolites [55-56]. In addition, crystalline $\alpha$-quartz is inactive and does not dissolve during zeolite synthesis.

The powder x-ray diffraction (XRD) patterns of PC fly ash samples re shown in Figs 1(b, c, d, e, h), and I, and CFB ashes in Fig. 3(a, f, g, and j). They include large numbers of peaks associated with crystalline phases and a substantial amorphous content, as shown by the large hump. The major difference in mineralogy of the fly ash was in the mullite content, which is characteristic for PC ash. The main components of the fly ash were the glassy aluminium-silicate matrix, mullite, quartz and magnetite. PC ash also contained amorphous aluminosilicates, which represented a wide peak from $15^{\circ}$ to $35^{\circ} 2 \Theta$. The amorphous phase in fly ash can be above $80 \%$. PC ash without and with FGD products were characterized by similar mineralogical composition. They contained mainly two crystalline phases: mullite and quartz. There were also significant amounts of hematite $(4,5)$, maghemite $(2,3)$, small periclase $(2-5)$ and silicate minerals: forsterite (2). Fly ash with FGD products were characterized by the content of calcium minerals such as anhydrite (3-5) and lime oxide (2, 3, $5)$. Lignite $\mathrm{PC}$ ash $(8,9)$ consisted primarily of quartz, anhydrite, periclase, $\mathrm{CaCO}_{3}(8)$, mullite (8), lime oxide (8), and portlandite (8). In the case of sample 8 , mullite was not detected.

D.R. Hodgson noticed that PC fly-ash contains minerals such as quartz, mullite, hematite, magnetite, calcite and borax, and oxidation of $\mathrm{C}$ and $\mathrm{N}$ during combustion drastically reduces their quantity in ash [57].

CFB ash $(1,6,7,10)$ mainly contained anhydrite, quartz, periclase, natrite, $\mathrm{CaCO}_{3}$, muscovite, and hematite $(6,7)$. In addition, albite (1), microcline (6), and iron oxide $(1,10)$ were also present.

The content of particular crystalline phases present in the 10 fly ashes are shown in Table 1.3. The most crystalline quartz was found in fly ash No. 8. In fly ash No.2 the content of the second crystalline component, mullite, was at the highest level. The highest level of anhydrite was observed in PC ash No. 8 and in CFB ash Nos. 1, 7 and the highest amount of the calcite was in CFB ash Nos. 1, 7 and 8 (PC ash). The amorphous phase of PC fly ash was much higher than that of CFB ash, and the highest was in fly ash No. 9. The crystalline phase of CFB fly ash was much higher than that of PC ash, and the highest was in fly ash No. 7. The exception was ash No. 8. The amorphous phase of this fly ash was the lowest and the crystalline phase was the highest. Quartz and aluminosilicates were found in all these ashes.

According to Ram [58], the aluminosilicates (mullite and gehlenite) were probably formed during combustion, possibly from kaolinite commonly present in raw coals and lignites. While according to van Dyk [59], the formation of Al-silicates from the reaction of $\gamma-\mathrm{Al}_{2} \mathrm{O}_{3}$ with free silica $\left(\mathrm{SiO}_{2}\right)$ was also possible, but as $\gamma-\mathrm{Al}_{2} \mathrm{O}_{3}$ is not very common in coal, this possibly happens via the formation of an intermediate product $\left(\mathrm{Al}_{2} \mathrm{Si}_{2} \mathrm{O}_{5}\right)$. Results of these studies confirmed the strong influence of combustion technology, fuel type, and FGD product on mineralogical composition of fly ash.

All the methodologies synthesizing zeolites from fly ashes are based on the dissolution of Al-Si-bearing fly ash phases with alkaline solutions $(\mathrm{NaOH}$ and $\mathrm{KOH}$ solutions) and the subsequent precipitation of zeolitic material. The reaction time needed to achieve the acceptable yields of zeolite synthesis is inversely proportional to the aluminium-silicate glass content of the fly ash. Querol noticed that for higher aluminumsilicate glass content, shorter activation periods and lower solution/fly ash rates are needed to reach high zeolite synthesis yields [32].

The efficiency of fly ash conversion is also dependent on the contents of non-reactive phases (mainly hematite, magnetite, lime) and resistant aluminumsilicate phases, such as mullite and quartz, and the grain 

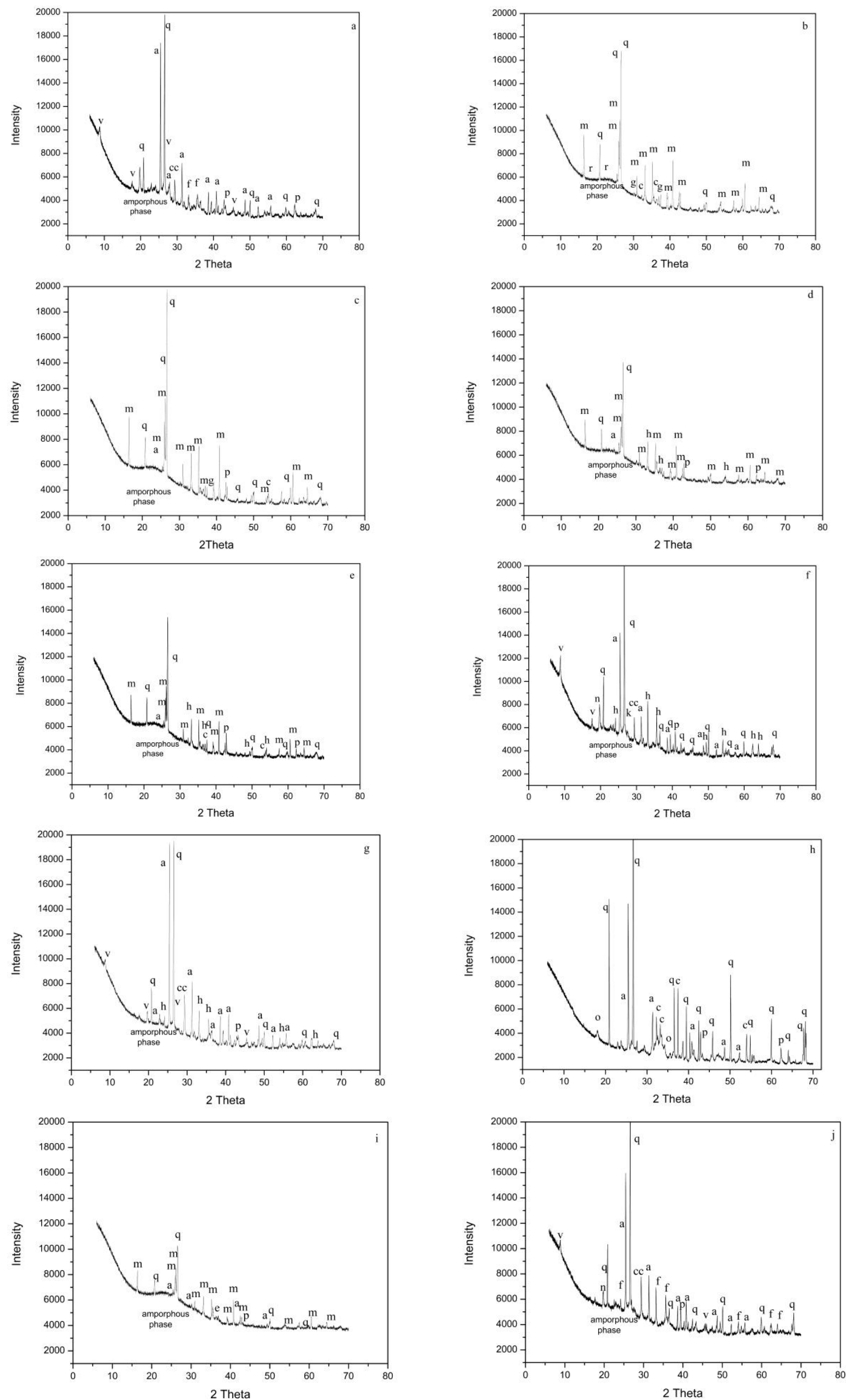

Fig.1. X-ray diffraction analysis of the obtained phases (q-quartz $\left(\mathrm{SiO}_{2}\right)$, m-mullite $\left(\mathrm{Al}_{6} \mathrm{Si}_{2} \mathrm{O}_{13}\right)$, h-hematite $\left(\alpha\right.$-Fe $\left.\mathrm{O}_{3}\right)$, a-anhydrite $\left(\mathrm{CaSO}_{4}\right)$, cc-calcite $\left(\mathrm{CaCO}_{3}\right)$, v-muscovite $\left(\mathrm{KAl}(\mathrm{Si}, \mathrm{Al})_{4} \mathrm{O}_{10}(\mathrm{OH})_{2}\right)$, a-albite $\left(\mathrm{NaAlSi}_{3} \mathrm{O}_{8}\right)$, p-periclase $(\mathrm{MgO})$, c-calcium oxide $(\mathrm{CaO})$, o-portlandite $\left(\mathrm{Ca}(\mathrm{OH})_{2}\right)$, g-maghemite $\left(\gamma\right.$ - $\left.\mathrm{Fe}_{2} \mathrm{O}_{3}\right)$, r-forsterite $\left(\mathrm{Mg}_{2} \mathrm{SiO}_{4}\right)$. 
Tab. 3. Mineralogy of fly ash determined by XRD.

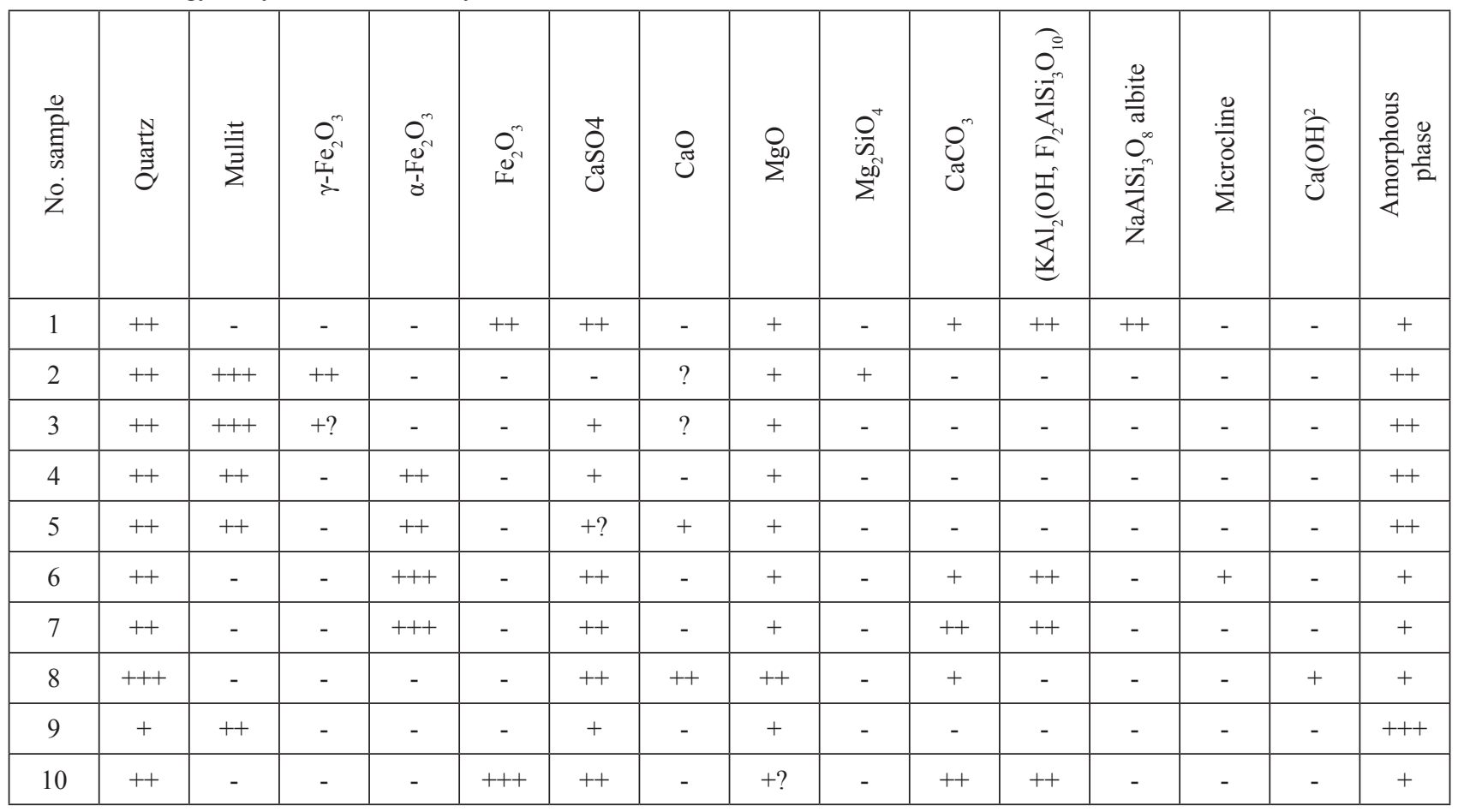

*The presence of an identified crystalline phase and amorphous substance is marked with crosses $(+):(+++)$ - significant content of the component, $(++)$ - average content of the component, $(+)$ - insignificant amount of the component $(+?)-$ trace amount of the component, (-) - lack of the phase or amount lower than the level of detectability by means of the x-ray method

size distribution. The Al- and Si-bearing phases are dissolved during different stages of the zeolitization in the order glass $>$ quartz $>$ mullite. It is therefore important to determine the mineralogical composition. According to research, fly ash Nos. 2, 3,4,5,6, 9 and 10 were rich in $\mathrm{SiO}_{2}$ content. The higher contents of resistant aluminumsilicate phases such as mullite and quartz were in the case of fly ash Nos. 3-5, 8 and 9. The total amount of quartz, mullite and other crystalline phases was large in fly ash Nos. 1, 6, 7, 8 and 10, leading to a small amount of the glass content in these fly ashes. The highest content of glass was identified in fly ash Nos. 2-5 and 9, and thus fly ash can be converted to zeolites.

\section{Morphology of Fly Ash}

The analysis of the morphology and the porous structure is required to the quality control of the converted fly ash and to compare the source material, intermediate and product.

In order to determine the morphology and the porous structure, the samples of fly ash were subjected to an analysis of SEM-EDX scanning microscopy. The results are presented in Fig. 2. The SEM pictures were shown differences between the PC ashes and CFB ashes. The dominant particles of CFB fly ash contained mainly coarse and angular, flaky, drossy, and irregular particles with a broad particle size range [60]. The porous and irregular CFB fly ash particles had a larger specific surface area than spherical particles.
The morphology of a fly ash particle was controlled by combustion temperature and cooling rate. The PC ashes from the burning of hard coal are presented in Fig. 2(b-e) from the burning of lignite in Fig. 2(h-i). The CFB ashes are presented in Fig. 2(a, f, g, j). The PC ashes were a composition of spherical particles

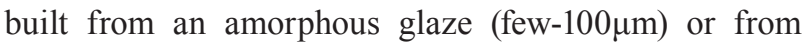
glaze comprising slightly crystalline mullite. In the fly ash samples (Nos. 2, 3, 4, 5, 8, 9) there were spherical, porous spheres that were empty inside of so-called ceno-sphere or fulfilled with fine spherical grains of so-called plenosphere (Fig. 2b, c, d, e, h, i). In some of the fly ashes there were also grains generating aggregates. In all fly ashes we also observed irregularly shaped unburned carbon particles. The thick fractions also contained glassy slag or quartz. A similar morphology was observed in the case of fly ashes obtained from combustion of lignite (Fig. 2f, i). In the FGD-PC ashes we noted mineral grains as a product of desulfurization such as calcite, calcium oxide, portlandite, gypsum and anhydrite. Calcium phase carbonate, sulfate, and oxides created separate aggregates or a crust-like surface on original components of the ashes. They could have been created by cementation occurring as a result of the amalgamation of glassy grains with calcium phase [61]. In the case of lignite PC ashes we observed ceneo- and pleno-spheres. On top of the grains of the glaze there were noticeable indigenous crust-like surfaces built of sulfate phase. In the CFB ashes we observed a big morphological differentiation of crystalline products and 

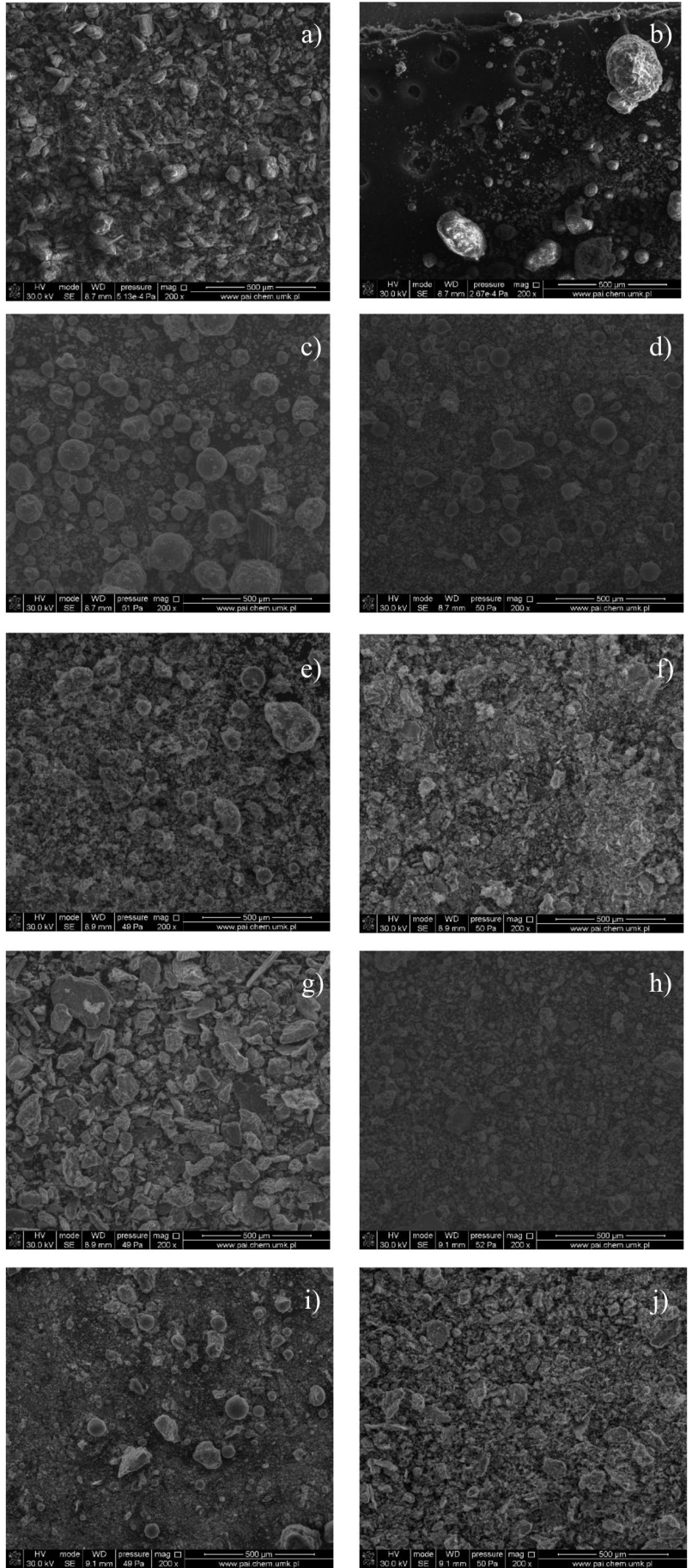

Fig. 2. SEM photographs of the fly ash (CFB ashes-a, f, g, j, PC ashes $-\mathrm{b}, \mathrm{c}, \mathrm{d}, \mathrm{e}, \mathrm{h}, \mathrm{i})$.

the grains were of very different shapes (from spherical to lamellar) and of diverse size $(1-10 \mu \mathrm{m})$. The anhydrite - product of desulphurization was observed as strongly diverse condensed and defected shapes. The multimineral subangular particles of fly ash often consisted of a core of quartz or aluminosilicate that reacted with calcium to produce a calcium-rich aluminosilicate followed by calcium and iron oxides [62]. The grains of $\mathrm{CFB}$ ash had irregular shapes because in the temperature of the CFB boiler, mineral substances accompanying
Table 4. BET-specific surface areas of the fly ash samples.

\begin{tabular}{|c|c|}
\hline Ash & BET Surface area $\mathrm{S}_{\mathrm{BET}} \mathrm{m}^{2} / \mathrm{g}$ \\
\hline 1. & 9.89 \\
\hline 2. & 3.20 \\
\hline 3. & 0,79 \\
\hline 4. & 2,88 \\
\hline 5. & 4.94 \\
\hline 6. & 6.64 \\
\hline 7. & 3.48 \\
\hline 8. & 1.09 \\
\hline 9. & 13.05 \\
\hline 10. & 3.13 \\
\hline
\end{tabular}

the coal were not subject to partial melting. Due to low temperature in the CFB boiler, in the CFB ash mullite was not present. The CFB ash was not included in the glassy phase as well, which is typical for PC ash.

The results suggest that the cenospheres in fly ash were amorphous aluminosilicate that could be easily transformed into soluble sodium silicate in the alkalifusion process for the production of mesoporous materials.

\section{BET Specific Surface Area}

The analysis of the specific surface area and adsorption-and-desorption isotherms is required for quality control of the converted fly ash and to compare the source material, intermediate and product. Low-temperature nitrogen adsorption was used to characterize porous materials. Table 4 shows the specific surface area (BET) of PC and CFB ashes.

The specific surface area $\left(\mathrm{S}_{\text {B.E.T. }}\right)$ of fly ash ranged from $0.79 \mathrm{~m}^{2} / \mathrm{g}$ (3) to $13.05 \mathrm{~m}^{2} / \mathrm{g}$ (9). Higher capacity was characteristic of CFB ashes rather than the PC ashes. However, the highest level of specific surface area was observed for PC ash No. $9\left(13.05 \mathrm{~m}^{2} / \mathrm{g}\right)$ due to this ash having the smallest grain size. Different values of the specific surface area of each ash showed that the specific surface area depended significantly on the conditions and type of combustion. The specific surface area was affected by the particle size distribution and particle shape. A higher specific surface area can be due to either large amounts of spongy minerallic particles in CFB fly ash (sample Nos. 1, 6, 7 and 10) or a significant amount of porous carbon particles (Nos. 1, 2, 5 and 9).

Fig. 3a) shows the $\mathrm{N} 2$ adsorption isotherm at $77 \mathrm{~K}$ for $\mathrm{PC}$ ash and Fig. 3b) for CFB ash.

$\mathrm{N}_{2}$ adsorption isotherms for all ashes were classified according to IUPAC regulations as isotherms of type II. This type of isotherm is typical for macro-pors materials, and is connected to situations in which low relative partial pressures of an adsorptive on a surface 
a)

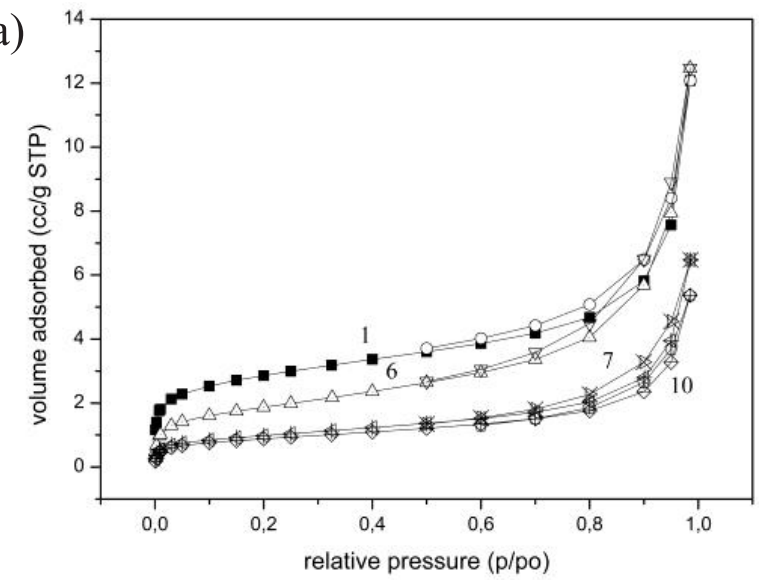

b)

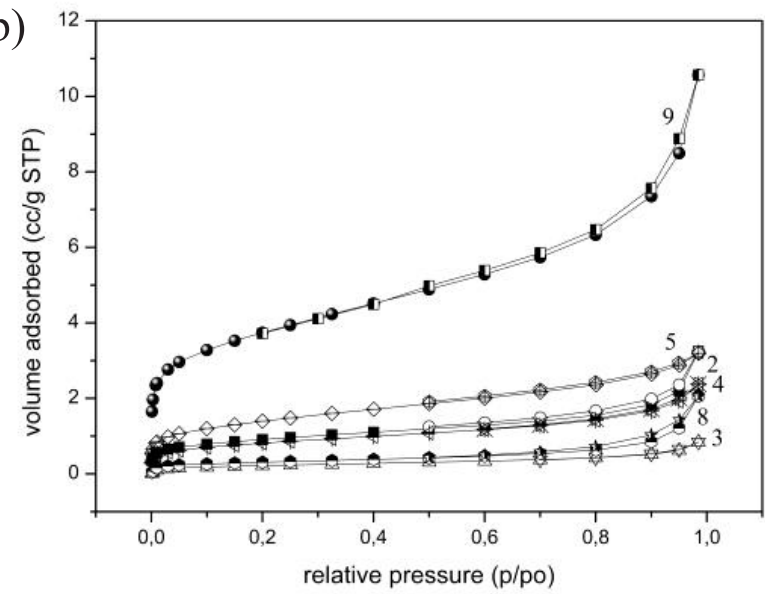

Fig. 3. N2 adsorption isotherm for a) CFB ash, b) PC ash.

of an adsorbent result in the occurrence of some monomolecular mini-layer of the adsorbed substance $\left(\mathrm{N}_{2}\right)$, whereas in the case of high relative partial pressures some multi-molecular layer of adsorbent on the surface of adsorbent is created. In the isotherms of the fly ash we observed that the loop of hysteresis (type H3) begins with relative low pressures that prove a low content of micropores in that structure. The loop of $\mathrm{H} 3$ hysteresis is typical for adsorbents with pores formed in the shape of gaps. The widest loop of hysteresis was observed in the case of ash (9), which shows that this sample had the highest volume of pores among the investigated ashes. A higher increase of $\mathrm{N}_{2}$ adsorption with low level of relative pressure $\left(\mathrm{p} / \mathrm{p}_{0}\right)$ pointed out a larger amount of micropores in the fly ash sample.

\section{Particle Size Distribution}

The most important physical characteristics determining the reactivity of coal fly ash is particle size. The particle size analysis by laser scattering analyzer for all fly ash was presented in Table 4. A three-point specification including $\mathrm{D}_{10}, \mathrm{D}_{50}$, and $\mathrm{D}_{90}$ particle size values offer appropriate information for presenting the particle size span width of fly ash. $\mathrm{D}_{50}$ is the diameter that splits the distribution with half above and half below this diameter. The $\mathrm{D}_{90}$ and $\mathrm{D}_{10}$ represent the coarsest and finest parts of the distribution, respectively. The differential particle size distributions of fly ash were in a range of from 0.39 to 590 microns. Ashes 1, 6, 7, 8, and 10 (Fig. 4a) had similar distribution of the grain volumes; and analogically ashes 2,3 and 5 . It was different in the case of ashes 4 and 9, which had other distribution of grain volumes. The distribution of grains of the fly ashes were divided into 3 groups: (a) standard Gauss distribution - for 1 sample of fly ash, (b) asymmetric distribution - for 7 samples of the ash, and (c) bimodal distribution - for only 2 sample of the fly ash. The volume-weighted percentiles $\mathrm{D}_{10}, \mathrm{D}_{50}$, and $\mathrm{D}_{90}$ of fly ash were reported in Table 5 and the cumulative curve of all fly ashes were shown in Fig. 4b). Ninety percent of the particles for fly ash Nos. 1, 4, 6, 9 and 10 had diameters smaller than $87.03 \mu \mathrm{m}, 97 \mu \mathrm{m}, 27 \mu \mathrm{m}$, $83 \mu \mathrm{m}, 16 \mu \mathrm{m}, 99.41 \mu \mathrm{m}$ and $100.50 \mu \mathrm{m}$ respectively and for fly Nos. 2 and 3 had diameters smaller than $228.47 \mu \mathrm{m}$ and $216.53 \mu \mathrm{m}$ respectively. The lignite ashes had $90 \%$ of their particles with sizes of less than $122 \mu \mathrm{m}$ and $99.41 \mu \mathrm{m}$ respectively. The abundance of fine particles in the lignite ash (no. 9) is attributable to the fact that lower rank coals typically contain substantial proportions of organically bound inorganic elements, such as $\mathrm{Ca}, \mathrm{Mg}$, and $\mathrm{Na}$, which are likely to form finer sized ash particles [59]. The data for the $\mathrm{D}_{50}$ values for the lignite fly ashes were less than $5.81 \mu \mathrm{m}$ and for PC ashes were less than $66.15 \mu \mathrm{m}$ (no. 2) and $74.90 \mu \mathrm{m}$ (no. 3). Ten percent for fly ashes no. 4 and 9 had diameters smaller than $1.77 \mu \mathrm{m}, 1.33 \mu \mathrm{m}$, respectively and for the $\mathrm{CFB}$ ashes had diameters smaller than $8.66 \mu \mathrm{m}$. The $\mathrm{CFB}$ ashes contained smaller particles than PC ashes, which was caused by combustion technology.

The particle sizes of the starting materials-fly ash plays an important role in determining the reactivity of CFA, with smaller particles exhibiting higher reactivity due to higher specific surface area. In the synthesis, mesoporous materials from fly ash a large particles require grinding to powder. In a study performed by Misran [54], the mean particle size of as-received CFA used as starting materials was about $6 \mu \mathrm{m}$. Thus to increase the reactivity of fly ashes, some ashes should be ground.

\section{Thermal Gravimetric Analysis}

Thermal analysis can provide important information about the thermal behaviour of the sample (phase transition, decomposition, etc.). In the synthesis, mesoporous materials from fly ash, in order to extract silicon from FA, a method in the fusion of FA with sodium hydroxide use [43, 49], is followed by dissolving the formed solid substance in water. Due to the fusion carried out at $550^{\circ} \mathrm{C}$, thermal analysis informing the phase behaviour and stability of fly ashes is required. The TGA analysis is also important to the quality control of the synthesis mesoporous materials and zeolites from 

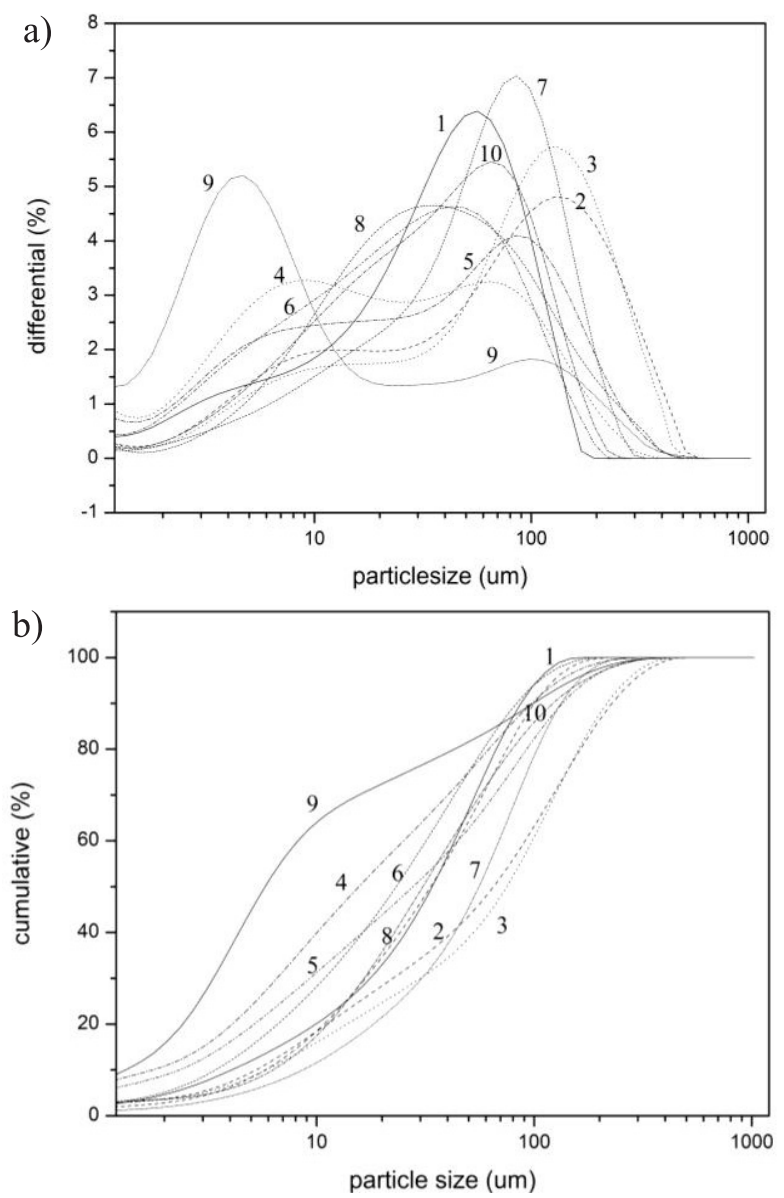

Fig. 4. a) Differential particle size distribution of fly ashes, b) cumulative particle size distribution of fly ashes.

fly ash and to compare the source material, intermediate and product.

Fig. 5 presents the $\mathrm{TG}$ and DTG curves during heating of the studied ashes under the nitrogen atmosphere. The TG (thermogravimetry) curve presents the weight loss of studied samples - in contrast to the initial mass under increasing temperature, and DTG

Table 5. Particle size distribution of fly ashes.

\begin{tabular}{|c|c|c|c|}
\hline Ash & $\mathrm{D}_{10}, \mu \mathrm{m}$ & $\mathrm{D}_{50}, \mu \mathrm{m}$ & $\mathrm{D}_{90}, \mu \mathrm{m}$ \\
\hline 1. & 4.07 & 34.05 & 87.03 \\
\hline 2. & 5.27 & 65.15 & 228.47 \\
\hline 3. & 5.88 & 74.90 & 216.53 \\
\hline 4. & 1.77 & 15.66 & 97.27 \\
\hline 5. & 2.34 & 27.77 & 135.33 \\
\hline 6. & 3.44 & 23.26 & 83.16 \\
\hline 7. & 8.66 & 55.82 & 133.28 \\
\hline 8. & 6.33 & 30.85 & 122.30 \\
\hline 9. & 1.33 & 5.81 & 99.41 \\
\hline 10. & 5.83 & 33.51 & 100.50 \\
\hline
\end{tabular}

(differential thermogravimetry) is based on the rate of weight loss with the increasing temperature.

In TGA of fly ash no. 1 showed two steps of degradation from $565^{\circ} \mathrm{C}$ to $777^{\circ} \mathrm{C}$ and from $777^{\circ} \mathrm{C}$ to $988^{\circ} \mathrm{C}$. The first zone, from $25-354^{\circ} \mathrm{C}$, corresponds to the removal of moisture and light volatiles with a total loss of about $0.69 \%$. This initial zone was followed by the active pyrolysis and oxidation zone from $354^{\circ} \mathrm{C}$ to $671^{\circ} \mathrm{C}$ with total degradation of $2.61 \%$. The first weight loss was observed between $565^{\circ} \mathrm{C}$ to $777^{\circ} \mathrm{C}$, with the total loss of $1.67 \%$ due to the calcium carbonate decomposition, and maximum weight loss was observed at $673^{\circ} \mathrm{C}$. The second weight loss was observed between $777^{\circ} \mathrm{C}$ to $988^{\circ} \mathrm{C}$, with total loss of $4.1 \%$ and maximum weight loss observed at $910^{\circ} \mathrm{C}$. The residue left at $988^{\circ} \mathrm{C}$ was ash and was about $88.28 \%$ of the original sample weight. TGA of fly ash no. 2 and no. 3 showed a single degradation of from $25^{\circ} \mathrm{C}$ to $354^{\circ} \mathrm{C}$. The first zone was $30-354^{\circ} \mathrm{C}$, with a total loss of about $0.14 \%$ for fly ash no. 2 and $0.0393 \%$ for no. 3. Above $354^{\circ} \mathrm{C}$ we observed a slow mass loss due to pyrolysis and oxidation. The residue left at $988^{\circ} \mathrm{C}$ was ash and was about $97.13 \%$ and $99.05 \%$ of the original sample weight. The thermal analysis of fly ash no. 4 shows three steps of degradation. The first weight loss was observed between $25^{\circ} \mathrm{C}$ to $354^{\circ} \mathrm{C}$, with a total loss of about $0,071 \%$. A weight loss maximum of $255^{\circ} \mathrm{C}$ was observed in the DTG curve. The second weight loss, between $460^{\circ} \mathrm{C}$ to $882^{\circ} \mathrm{C}$, shows the active pyrolysis and oxidation with total degradation of $0,28 \%$. The third weight loss was observed between $882^{\circ} \mathrm{C}$ to $988^{\circ} \mathrm{C}$, with total loss of $0,44 \%$. The maximum weight loss was centered on $960^{\circ} \mathrm{C}$. The residue left at $980^{\circ} \mathrm{C}$ was ash and was about $98,53 \%$ of the original sample weight. TGA of fly ash no. 5 shows a single step of degradation from $776^{\circ} \mathrm{C}$ to $987^{\circ} \mathrm{C}$. The first zone was $30-354^{\circ} \mathrm{C}$, with a total loss of about $0,027 \%$. This next was from $380^{\circ} \mathrm{C}$ to $671^{\circ} \mathrm{C}$, with total degradation of $0,263 \%$. The weight loss was observed between $776^{\circ} \mathrm{C}$ to $987^{\circ} \mathrm{C}$, with total loss of $1,32 \%$ and maximum weight loss observed at $905^{\circ} \mathrm{C}$. The residue left at $988^{\circ} \mathrm{C}$ was about $98,02 \%$ of the original sample weight. In the case of FA 6 , three steps of degradation were observed. The first weight loss was observed between $25^{\circ} \mathrm{C}$ to $143^{\circ} \mathrm{C}$, which corresponds to desorption of physically adsorbed water and light volatiles from the solid microstructure with a total loss of about $0,021 \%$. TG curve of fly ash no. 6 shows maximum weight loss at $75^{\circ} \mathrm{C}$. The second weight loss was observed between $565^{\circ} \mathrm{C}$ to $777^{\circ} \mathrm{C}$, with total degradation of $1,58 \%$, which was indicated by the decomposition of calcium carbonate. The third weight loss was observed between $777^{\circ} \mathrm{C}$ to $998^{\circ} \mathrm{C}$, with a total loss of $2.12 \%$ and maximum weight loss of $927^{\circ} \mathrm{C}$. The residue left at $980^{\circ} \mathrm{C}$ was about $95,53 \%$ of the original sample weight. In TGA of fly ash no. 7 shows a single step of degradation from $566^{\circ} \mathrm{C}$ to $777^{\circ} \mathrm{C}$. The first zone was from $30-540^{\circ} \mathrm{C}$, with a total loss of about $0,44 \%$. This initial zone was followed by the active decomposition of calcium carbonate zone from $565^{\circ} \mathrm{C}$ to $777^{\circ} \mathrm{C}$, with total degradation of $3,16 \%$. 

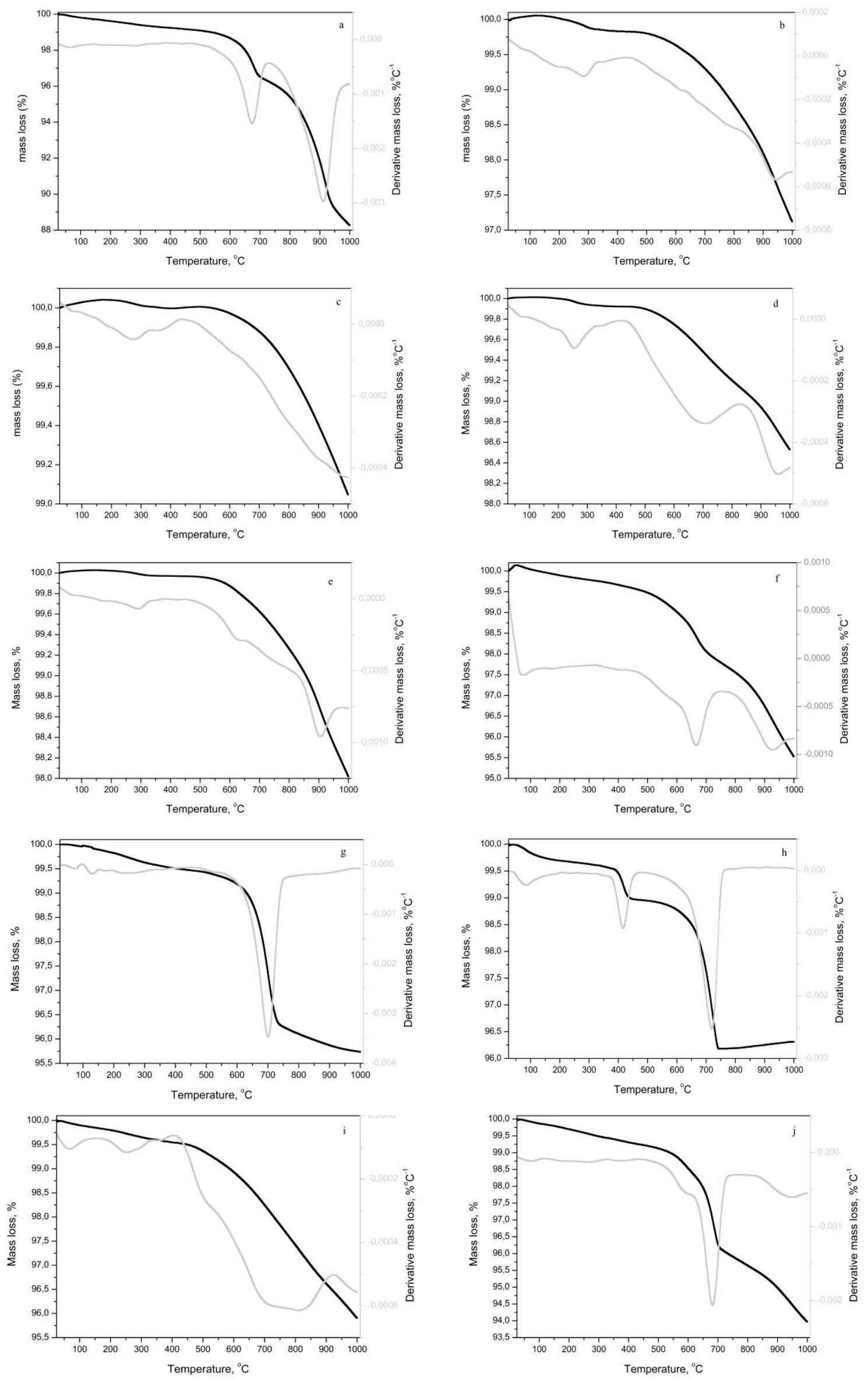

Fig. 5. TG and DTG curves for PC (b, c, d, e, h, i) and CFB (a, f, g, j) ash. 
The residue left at $988^{\circ} \mathrm{C}$ was about $95,73 \%$ of the original sample weight. Three steps of degradation were shown on TG curves of fly ash no. 8. The first weight loss was observed between $40^{\circ} \mathrm{C}$ to $143^{\circ} \mathrm{C}$ with total loss of about $0,24 \%$. Weight loss maximum at $84^{\circ} \mathrm{C}$ was observed in the DTG curve. The second weight loss between $354^{\circ} \mathrm{C}$ to $460^{\circ} \mathrm{C}$ was the result of the active decomposition of calcium hydroxide, with total degradation of $0,62 \%$. The DTG curve indicated that the transition was centered at around $416^{\circ} \mathrm{C}$. The third weight loss was observed between $566^{\circ} \mathrm{C}$ to $777^{\circ} \mathrm{C}$, with the total loss of $2,69 \%$. The maximum weight loss was centered on $719^{\circ} \mathrm{C}$ due to the decomposition of calcium carbonate. The sample weight remained almost constant with total degradation of $0.07 \%$ up to $777^{\circ} \mathrm{C}$. The residue left at $988^{\circ} \mathrm{C}$ was represented by ash and was about $96.31 \%$ of the original sample weight. In TGA of fly ash no. 9 we observed a single step of degradation from $460^{\circ} \mathrm{C}$ to $924^{\circ} \mathrm{C}$. The first zone was from $25-354^{\circ} \mathrm{C}$, with a total loss of about $0,4 \%$. The next zone was from $354^{\circ} \mathrm{C}$ to $671^{\circ} \mathrm{C}$, with total degradation of $1.13 \%$. The total degradation the weight loss between $671^{\circ} \mathrm{C}$ to $777^{\circ} \mathrm{C}$ was $0.89 \%$. The residue left at $998^{\circ} \mathrm{C}$ was about $95.91 \%$ of the original sample weight. In the TG curves of fly ash no. 10 we observed one-step degradation. The first weight loss was observed between $460^{\circ} \mathrm{C}$ to $777^{\circ} \mathrm{C}$, which was a result of the decomposition of calcium carbonate total loss of about $3.47 \%$. Weight loss maximum at $682^{\circ} \mathrm{C}$ was observed in the DTG curve. The residue left at $988^{\circ} \mathrm{C}$ was about $93.97 \%$ of the original sample weight.

Each phase is characterized by its own temperature range of decomposition and by a specific mass loss. In the first stage of the thermal processes, the release of moisture up about $100^{\circ} \mathrm{C}$ and to water of constitution and light volatiles from fly ash at low temperatures up to $450^{\circ} \mathrm{C}$. From $450^{\circ} \mathrm{C}$ the oxidation of coal occurs, while the oxidation of carbon by the iron oxides was observed in the $700-1000^{\circ} \mathrm{C}$ [63]. Khan reported that magnetite oxidizes to maghemite and hematite at 350 to $400^{\circ} \mathrm{C}$ and 600 to $800^{\circ} \mathrm{C}$ [64]. Due to several overlapping peaks, the minerals are difficult to identify. Most of the effects detected on the TGA diagrams are related to the loss of humidity between room temperature and approximately $300^{\circ} \mathrm{C}$. In conclusion, the weight losses of studied ashes with the increase of temperature take place due to moisture loss and the decomposition of some minerals (e.g., calcium carbonate).

\section{Conclusions}

To meet the growing energy demand and thereby increase power generating capacity, dependency on coal for power generation requires more environmentally friendly methods of fly ash utilization.

The high silica content of fly ash makes it a potentially useful source for the synthesis of nanoporous materials such as zeolites and mesoporous molecular sieve. The synthesis of these materials from fly ash is one of the methods of fly ash utilization.

This paper presented a study of physical and chemical properties of fly ashes and on the basis of these, fly ashes for the synthesis of zeolites and mesoporous materials were selected.

The parameter that determines ash usefulness as a zeolite is the $\mathrm{Si} / \mathrm{Al}$ ratio. Thus samples with the $\mathrm{SiO}_{2} / \mathrm{Al}_{2} \mathrm{O}_{3}$ ratio in the range of $1.67 \div 2.01$ can be converted to zeolite A. Samples with $\mathrm{SiO}_{2} / \mathrm{Al}_{2} \mathrm{O}_{3}$ ratio 2.16 and 2.18 can be converted to zeolite $\mathrm{X}$. Fly ash with $\mathrm{SiO}_{2} / \mathrm{Al}_{2} \mathrm{O}_{3}$ ratio 6.27 can be converted to zeolite Y. The samples with the highest content of $\mathrm{SiO}_{2}, \mathrm{Al}_{2} \mathrm{O}_{3}$ and glass can be used to synthesize molecular sieves. The most important physical characteristics determining the reactivity of coal fly ash is particle size. Results show that to increase the reactivity of fly ashes in the synthesis of mesoporous materials, some ashes should be ground.

The presented analyses of the morphology, porous structure, specific surface area and adsorption-anddesorption isotherms is required for the quality control of the converted fly ash and to compare the source material, intermediate and product. Thermal analysis provided important information about the thermal behaviour and stability of fly ashes of the samples.

Generally, the results of our study confirmed that fly ashes can be used to synthesize zeolites and mesoporous materials.

\section{Acknowledgements}

The research was financed by The National Science Centre in Poland, based on the decision DEC-2011/03/B/ ST8/05916. The part of research was financed by statutory funds no. BSPB-406-301/11.

\section{Conflict of Interest}

The authors declare no conflict of interest.

\section{References}

1. Environment 2017, Statistical Information and Elaborations, Central Statistical Office, https://stat.gov. pl/obszary-tematyczne/srodowisko-energia/srodowisko/ ochrona-srodowiska-2017,1,18.html, Warsaw, 2017.

2. SAHA A.K. Effect of class $F$ fly ash on the durability properties of concreto. Sustainable Environment Research, 28 (1), 25, 2018.

3. WEI Z., WANG B., FALZONE G., LA PLANTE E .C., OKORONKWO M.U., SHE Z., OEY T., BALONIS M., NEITHALATH N., PILON L., SANT G. Clinkeringfree cementation by fly ash carbonation. Journal of $\mathrm{CO}_{2}$ Utilization, 23, 117, 2018.

4. BAI J., YANG X., XU S., JING W., YANG J. Preparation of foam glass from waste glass and fly ash. Materials Letters, 136, 52, 2014. 
5. WANG S., ZHANG C., CHEN J. Utilization of coal fly ash for the production of glass-ceramics with unique performances: a brief review. Journal of Materials Science \& Technology, 30 (12), 1208, 2014.

6. PARK J.S., TANIGUCHI S., PARK Y.J. Alkali borosilicate glass by fly ash from a coal-fired power plant. Chemosphere, 74 (2), 320, 2009.

7. LIN B., LI S., HOU X., LI H. Preparation of high performance mullite ceramics from high-aluminum fly ash by an effective method. Journal of Alloys and Compounds, 623, 359, 2015.

8. SHAHEEN S. M., HOODA P.S., TSADILAS C.D. Opportunities and challenges in the use of coal fly ash for soil improvements - A review. Journal of Environmental Management, 145, 249, 2014.

9. SKOUSEN J., ZIEMKIEWICZ P., YANG J.E. Use of coal combustion by-products in mine reclamation: review of case studies in the USA. Geosystem Engineering, 15 (1), 71, 2012

10. DING J., MA S., SHEN S., XIE Z., ZHENG S., ZHANG Y. Research and industrialization progress of recovering alumina from fly ash: A concise review. Waste Management, 60, 375, 2017.

11. COLANGELO F., CIOFFI R., MONTAGNARO F., SANTORO L. Soluble salt removal from MSWI fly ash and its stabilization for safer disposal and recovery as road basement material. Waste Management, 32 (6), 1179, 2012.

12. FAN F., LIU Z., XU G., PENG H., CAI C.S. Mechanical and thermal properties of fly ash based geopolymers. Construction and Building Materials, 160, 66, 2018.

13. ZHANG Y., ZHANG Z., LIU Z., NORRIS P., PAN W-P. Study on the mercury captured by mechanochemical and bromide surface modification of coal fly ash. Fuel 200, 427, 2017.

14. ŚCIUBIDŁO A. Synthesis of sorbents for exhaust gases purification. Advanced $\mathrm{CO}_{2}$ capture technologies for clean Energy generation, Monographs 320, 63, 2016.

15. ŚCIUBIDŁO A. Utilization of fly ash as low-cost adsorbents. Rynek Energii, 6 (133), 80, 2017. [In Polish]

16. REZAEI F., ROWNAGHI A.A., MONJEZI S., LIVELY R.P., JONES C.W. $\mathrm{SO}_{x} / \mathrm{NO}_{x}$ removal from flue gas streams by solid adsorbents: a review of current challenges and future directions. Energy\&Fuels, 29 (9), 5467, 2015.

17. ŚCIUBIDŁO A., NOWAK W. Novel sorbents for flue gas purification, Journal of Power Technologies. 92 (2), 115, 2012.

18. ŚCIUBIDŁO A., NOWAK W. Cleaning of exhaust gases of nitrogen oxides using sorbents from fly ashes. Polska Inżynieria Środowiska, 1, 299, 2012 [In Polish].

19. MAJCHRZAK-KUCĘBA I. Solid adsorbents used in VPSA adsorption units for $\mathrm{CO}_{2}$ capture from coal-fired power plants. Advanced $\mathrm{CO} 2$ capture technologies for clean Energy generation, Monographs 320, 25, 2016.

20. MAJCHRZAK-KUCĘBA I., BUKALAK-GAIK D. Testing of porous materials and establishing their $\mathrm{CO}_{2}$ adsorption potential, Advanced $\mathrm{CO} 2$ capture technologies for clean Energy generation, Monographs 320, 53, 2016.

21. SARMAH M., BARUAH B.P., KHARE P. A comparison between $\mathrm{CO}_{2}$ capturing capacities of fly ash based composites of MEA/DMA and DEA/DMA. Fuel Processing Technology, 106, 490, 2013.

22. ZHOU L., CHEN Y., ZHANG X., TIAN F., ZU Z-N. Zeolites developed from mixed alkali modified coal fly ash for adsorption of volatile organic compounds. Materials Letters, 119, 140, 2014.
23. ŚCIUBIDŁO A., NOWAK W., MAJCHRZAK-KUCĘBA I. Characterization of zeolites from polish fly ashes. $26^{\text {th }}$ Annual International Pittsburgh Coal Conference, Pittsburgh, 20-23 September 2009.

24. MAJCHRZAK-KUCĘBA I., ŚCIUBIDŁO A., NOWAK W. Synthesis of zeolite Na-X from fly ashes. Sorbenty $\mathrm{z}$ popiołu dla energetyki, 39, 2010 [In Polish].

25. ZHANG Z., XIAO Y., WANG B., SUN Q., LIU H. Waste is a misplayed resource: synthesis of zeolites from fly ash for $\mathrm{CO}_{2}$ Capture. Energy Procedia, 114, 2537, 2017.

26. FUKASAWA T., KARISMA A.D., SHIBATA D., HUANG A-N., FUKUI K. Synthesis of zeolite from coal fly ash by microwave hydrothermal treatment with pulverization process. Advanced Powder Technology, 28 (3), 798, 2017.

27. MAJCHRZAK-KUCĘBA I., ŚCIUBIDŁO A., NOWAKW. Studies on the properties of mesoporous materials derived from polish fly ashes. $26^{\text {th }}$ Annual International Pittsburgh Coal Conference, Pittsburgh, 20-23 September 2009.

28. LI C-C., QIAO X-C. A new approach to prepare mesoporous silica using coal fly ash. Chemical Engineering Journal, 302, 388, 2016.

29. FERRARINI S.F., CARDOSO A.M., PAPROCKI A., PIRES M. Integrated Synthesis of Zeolites Using Coal Fly Ash: Element Distribution in the Products, Washing Waters and Effluent. Journal of the Brazilian Chemical Society, 27 (11), 2034, 2016

30. TAUANOV Z., SHAH D., INGLEZAKIS V., JAMWAL P.K. Hydrothermal synthesis of zeolite production from coal fly ash: A heuristic approach and its optimization for system identification of conversion. Journal of Cleaner Production, 182, 616, 2018.

31. ŚCIUBIDŁO A., ŚCIUBIDŁO P. Utilization of fly ash in environmental engineering. Journal of Civil Engineering, Environment And Architecture, 64 (4/17), 247, 2017.

32. QUEROL X., MORENO N., UMANA J.C., ALASTUEY A., HERNANDEZ E., LOPEZ-SOLER A., PLANA F. Synthesis of zeolites from coal fly ash: an overview. International Journal of Coal Geology, 50, 413, 2002.

33. ZHAO X.S., LU G.Q., ZHU H.Y. Effects of ageing and seeding on the formation of zeolite $\mathrm{Y}$ from coal fly ash. Journal of Porous Materials, 4, 245, 1997.

34. KOSHY N., SINGH D.N. Fly ash zeolites for water treatment applications. Journal of Environmental Chemical Engineering, 4 (2), 1460, 2016.

35. PEDROLO D.R.S., DE MENEZES QUINES L.K., DE SOUZA G., MARCILIO N.R. Synthesis of zeolites from Brazilian coal ash and its application in $\mathrm{SO}_{2}$ adsorption. Journal of Environmental Chemical Engineering, 5 (5), 4788, 2017.

36. ZHANG Z., XIAO Y., WANG B., SUN Q., LIU H. Synthesis of zeolites from fly ash for $\mathrm{CO}_{2}$ capture. Energy Procedia, 114, 2537, 2017.

37. LEE Y.R., SOE J.T., ZHANG S.Q., AHN J.W., PARK M.B., AHN W.S. Synthesis of nanoporous materials via recycling coal fly ash and other solid wastes: A mini review, Chemical Engineering Journal, 317, 821, 2017.

38. MAJCHRZAK-KUCĘBA I. Thermogravimetry applied to characterization of fly ash-based MCM-41 mesoporous materials. Journal of Thermal Analysis and Calorimetry, 107, 911, 2012.

39. BHAGIYALAKSHMI M., YUN L.J., ANURADHA R., JANG H.T. Synthesis of chloropropylamine grafted mesoporous MCM-41, MCM-48 and SBA-15 from rice husk ash: their application to $\mathrm{CO}_{2}$ chemisorption. Journal of Porous Materials, 17, 475, 2010. 
40. MURESEANU M., CIOATERA N., TRANDAFIR I., GEORGESCU I., FAJULA F., GALARNEAU A. Selective $\mathrm{Cu}^{2+}$ adsorption and recovery from contaminated water using mesoporous hybrid silica bio-adsorbents. Microporous and Mesoporous Materials, 146, 141, 2010.

41. CHANDRASEKAR G., KIM J., YOU K.S., AHN J.W., JUN K.W., AHN W.S. Synthesis of hexagonal mesoporous aluminophosphate using Al dross. Korean Journal of Chemical Engineering, 26 (5), 1389, 2009.

42. DHOKTE A.O., KHILLARE S.L., LANDE M.K., ARBAD, B.R. Synthesis, characterization of mesoporous silica materials from waste coal fly ash for the classical Mannich reaction. Journal of Industrial Engineering Chemistry, 17, 742, 2011.

43. ZHANG Y., KANG L., SHANG J., GAO H. A low cost synthesis of fly ash-based mesoporous nanocomposites for production of hydrogen by photocatalytic water-splitting, Journal of Materials Science, 48, 5571, 2013.

44. BOPAIAH S., GRUTZECK M.W. Adsorption of $\mathrm{SO}_{2}$ and NOx by zeolites synthesized from fly ash, cement klin dust and recycled bottle glass, Materials Research Laboratory, $522,2000$.

45. ŚCIUBIDŁO A. An innovative method for utilization of fly ash. Journal of Civil Engineering, Environmental and Architecture, XXXIII, 63 (3), 469, 2016 [In Polish].

46. ŚCIUBIDŁO A. Low-cost sorbents from fly ash; Ograniczanie emisji $\mathrm{CO}_{2}$ - przeciwdziałanie zmianom klimatu (red.) Majchrzak-Kucęba Izabela, Ściubidło Aleksandra; Monografie, 308, 136, 2016 [In Polish].

47. THEIS T.L., WIRTH J.L. Sorptive behaviour of trace metals on fly ash in aqueous systems. Environmental Science and Technology, 11, 1096, 1977.

48. KUMAR V., MATHUR M., KHARIA P.S. Fly ash management: vision for the new millennium. Technology Information Forecasting and Assessment Council, New Delhi, 25, 66, 2003.

49. SINGH S., RAM L.C., MASTO R.E., VERMA S.K. A comparative evaluation of minerals and trace elements in the ashes from lignite, coal refuse, and biomass fired power plants. International Journal of Coal Geology, 87 (2), 112, 2011.

50. WANG W., QIN Y., SONG D., WANG K. Column leaching of coal and its combustion residues, Shizuishan, China. International Journal of Coal Geology, 75 (2), 81, 2008.

51. BASU M., PANDE M., BHADORIA P.B.S., .MAHAPATRA S.C. Potential fly-ash utilization in agriculture: A global review, Progress in Natural Science, 19 (10), 1173, 2009.

52. KIELCOW N.W. ,, Fundamentals of adsorption technique”, Wydawnictwo Naukowo-Techniczne, Warszawa, Polska, 136, 1980 [In Polish].
53. RAYALU S.S., UDHOJI J.S. MUNSHI K.N., HASAN MZ. 2001. Highly crystalline zeolite - a from fly ash of bituminous and lignite coal combustion. Journal of Hazardous Materials, 88, 107, 2001.

54. MISRAN H., SINGH R., BEGUM S., YARMO M.A Processing of mesoporous silica materials (MCM-41) from coal fly ash. Journal of Materials Processing Technology, 186 (1-3), 8, 2007.

55. QUEROL X., PLANA F., ALASTUEY A., LÓPEZSOLER A. Synthesis of Na-zeolites from fly ash, synthesis of Na-zeolites from fly ash synthesis of Na-zeolites from fly ash, Fuel, 76, 793, 1997.

56. QUEROL X., UMANA J.C., PLANA F., ALASTUEY A.,LÓPEZ-SOLER A., MEDINACELI A., VALERO A., DOMINGO M.J., ROJO E.G. Synthesis of zeolites from fly ash at pilot plant scale. Examples of potential applications, Fuel 80, 857, 2001.

57. HODGSON D.R., HOLLIDAY R. The agronomic properties of pulverized fuel ash Chemistry and Industry, 20, 785, 1966.

58. RAM L.C. Moessbauer spectroscopic and gamma radiolytic studies of some indian coals. PhD thesis, Banaras Hindu University, Varanasi, India, 1992.

59. VAN DYK J.C. Understanding the influence of acidic components ( $\mathrm{Si}, \mathrm{Al}$, and $\mathrm{Ti}$ ) on ash flow temperature of South African coal sources. Minerals Engineering, 19 (3), 280, 2006.

60. LECUYER I., BICOCCHIL S., AUSSET P., LEFEVRE R. Physico-chemical characterization and leaching of desulphurization coal fly ash. Waste Management \& Research, 14 (1), 15, 1996.

61. RATAJCZAK T., GAWEŁ A., GÓRNIAK K., MUSZYŃSKI M., SZYDŁAK T., WYSZOMIRSKI P. Characteristics of fly ash from combustion of coal and lignite. Polskie Towarzystwo Mineralogiczne, Prace specjalne, 13, 1, 1999 [In Polish].

62. GOODARZI F. Characteristics and composition of fly ash from Canadian coal-fired power plants. Fuel, 85 (10-11), 1418, 2006.

63. PAYÁ J., MONZÓ J., BORRACHERO M.V., AMAHJOUR F., PERIS-MORA E. Losson ignition and carbon content in pulverized fuel ashes (PFA): two crucial parameters for quality control. Journal of Chemical Technology \& Biotechnology, 77 (3), 251, 2002.

64. KHAN U.S., AMANULLAH., MANAN A., KHAN N., MAHMOOD A., RAHIM A. Transformation mechanism of magnetite nanoparticles, Materials Science-Poland, 33 (2), 278, 2015. 